Dr Sarahleigh Castelyn

\title{
Choreographing HIV and AIDS in Contemporary Dance in South Africa
}

Sarahleigh Castelyn

HIV and AIDS affects all South Africans, whether they are HIV-positive or not and has marked both the personal and the political experience of South African society. It has also had a distinct impact on South African performance. Social scientist Corinne Squire emphasises that '[i]n high HIV-prevalence contexts such as South Africa ... HIV becomes everyone's problem' (2007: 9) and because of this, a number of choreographers working in the idiom of South African contemporary dance, make work that explores HIV and AIDS. In South Africa, HIV is predominantly sexually transmitted in the heterosexual section of the population. This is further complicated by the patriarchal character of South African society where female sexuality is frequently governed and controlled by societal customs around sex.

Commissioned by The Human Sciences Research Council (South Africa), The South African National HIV Prevalence, Incidence and Behaviour Survey, 2012 noted this high incidence and prevalence rate especially in young black South African women (2014: xiii). This essay explores how contemporary dance in South Africa reacts to the epidemic and its effect on young black South African women in its study of two choreographic works, Robyn Orlin's We must eat our suckers with the wrappers on (2001) and Uncles and Angels (2013) by Nelisiwe Xaba and Mocke $J$ van Veuren. It examines why the choreographers respond in this way, and how, due to the South African context, these responses are unique. South African society is conservative and the selected dance works in this essay graphically represent sex in their choreographies thereby illustrating what sociologist Deborah Posel, although referring to 'public health campaigns', states as “"get[ting] the nation [South Africa] talking about sex"' (2011: 135). Stigma surrounding the disease is another factor that shapes the South African experiences as HIV and AIDS researchers Catherine Campbell, Carol Ann Foulis, Sbongile Malmane and Zweni Sibya note: 'Stigmatization of people living with AIDS is a key obstacle to HIV prevention and AIDS care. It is now generally accepted that efforts to reduce stigma should be an integrated part of all HIV/AIDS programming' (2005: 5). These dance works investigate and represent the complexities of the experience of HIV and AIDS in 
South African society and demonstrate specific social factors and cultural practices that surround HIV transmission.

South African arts journalist Darryl Accone, writes that there has been an unfortunate development of a 'genre of performance: the Aids [sic] play/dance/musical' (2001). This is due to the dramatic influence HIV and AIDS has had on South African society, nevertheless, there are strong movements in the themes of these dance works - and in the actual choreographed movement languages - against simplifying the reality and experience of those affected by HIV and AIDS. This makes for often uncomfortable viewing for the audience and the works have been met by mixed critical response. The central argument of this essay is that these choreographies illustrate the need for a stronger heterogeneity in the representation of HIV and AIDS in performance and, in this case, representations that tally with the particular circumstances of the South African experience of the virus. This includes a recognition of the gendered and racial inequality that shapes the disease and its effects. South African theatre scholar Alex Sutherland argues that:

On the one hand, women are appropriated in the 'new' South Africa as symbols of national strength and endurance in mainstream nation-building efforts and women's rights and equality are guaranteed by the constitution. However, the role and treatment of women outside of this imagined nation is radically different. Gross inequalities exist, particularly within intimate settings, which are often dominated by gender-based violence. In this climate it is naive and ignorant to preach condom use and abstinence as means of combating HIV, when women often have very little negotiating power in sexual relations. (2013: 179)

HIV and AIDS has had a great impact on my own personal and political experience of South Africa, particularly as a woman in intimate and social settings. It is necessary to acknowledge of my subject position as an apartheid classified white South African woman writing an essay that is concerned with how the chosen dance works represent the experience of black South African women and HIV and AIDS. Moreover, as HIV and AIDS researchers, Salim S Abdool Karim, Gavin J Churchyard, Quarraisha Abdool Karim, and Stephen D Lawn, clearly state:

The social, economic, and environmental conditions created by apartheid - such as overcrowded squatter settlements, migrant labour, and deliberately underdeveloped 
health services for black people - provided a favourable environment for efficient transmission of HIV (2009: 921).

Therefore, it is crucial to acknowledge that for black South Africans this experience of HIV and AIDS is far more acute than other racial groupings. In addition, the selected choreographies focus far more on heterosexual sex and HIV-transmission; still, it is important to recognise that HIV and AIDS shapes the lives of gay, bisexual, and trans* South Africans too.

The primary focal point of this essay is the role gender and race plays in HIV and AIDS discourse but the secondary concern is the indigenous specificity of South African culture, such as the part indigenous healers play in the prevention and/or the transmission of the virus, and the uneasy relationship between the indigenous healing and medical communities. What is common to both themes of this essay is the constant fluid negotiation between traditional and contemporary South African culture; the equal rights of women written into the South African constitution (1996) but the reality of this on the streets and between the sheets, and the conflict between treatment offered by medical professionals and that tendered by indigenous healers. What both choreographies show is that it is important to acknowledge the state of flux in which these aspects of South African culture operate, and how they are not in opposition, but rather are found in various points of crossover with each other, and therefore why it is important that dance performance represents the heterogeneity of the experience of HIV and AIDS in South Africa.

The scope and focus of this research is predominantly concerned with how HIV and AIDS is represented in the selected contemporary dance works, how the South African experience of the virus is explored through them, and why South African choreographers respond in such a way due to the specifics of the South African setting. However, the essay will not provide the reader with a detailed history of HIV and AIDS in South Africa nor an indepth analysis of the biology of the virus. What the chosen choreographies will show is the shift in the South African understanding and reaction to HIV and AIDS across a decade (2001 to 2013) and how there has been an appropriation of certain cultural practices in HIV prevention campaigns. What must be underlined, though, is that when researching and writing about HIV and AIDS in South Africa, there must be an honest acknowledgement of how apartheid and colonialism and their legacies - from limited access to health and education, lack of services such as water and electricity, decent homes, and other forms of social engineering - have shaped the negative forces the disease has had on a majority of 
South Africans. 'These historical conditions continue to define the nature of the HIV [...] epidemics in South Africa' (Karim et al, 2009: 921). The essay analyses how contemporary dance choreographers in South Africa respond to HIV and AIDS in their dance works and how this reply is unique because of South Africa's patriarchal and racialised society and the intersection of contemporary medical and traditional healing practices. As medical theorist Paula Treichler notes,

Understanding the AIDS epidemic as a medical phenomenon involves understanding it as a cultural phenomenon. Yet excessively and positivist or commonsensical notions of culture may limit our ability to recognize that AIDS is also a complex and contradictory construction of culture. This is particularly true of AIDS in developing countries.

(1999: 99; emphasis in original)

These choreographies call into question the discourses surrounding HIV and AIDS, its representations and the policies and campaigns in South Africa. The essay contextualises these responses and problematises whether these representations of HIV and AIDS on the dance stage reiterate or subvert stereotypes of the epidemic and its effects. Arts journalist Adrienne Sichel points out that 'South African contemporary dance has been, to a large extent, a political act of defiance and activism' (2012: 108) due to its origin and history in South Africa and the chosen contemporary dance works in this essay demonstrate this defiant activist attitude. Choreographers are able to represent through dance the complicated nature of South African social, sexual, racial and gender politics. This is important as the two productions tour both locally and internationally from Johannesburg to Paris. In South Africa, the choreographies highlight the successes and limitations of HIV and AIDS health campaigns for local audiences, and, in European contexts, the performances are able to raise awareness of the problematic construction of negative stereotypes around South Africa and the disease.

Robyn Orlin is an internationally renowned white South African choreographer who has been at the forefront of the contemporary national dance scene since the 1980s and has been recipient of a number of awards. She was the first to receive the AA Vita Award (South Africa) for Choreography in 1985 and in 2003 was awarded the Laurence Olivier (United Kingdom) for Daddy, I've seen this piece six times before and I still don't know why they're hurting each other. Her works often have lengthy titles in order to reflect the complexities of 
the South African experience that she explores in her choreography. The title of We must eat our suckers with the wrappers on (2001) is derived from a South African township idiom referring to condom use'. Orlin created this work in light of the 'financial scandal' (Fassin, 2007: xvii) of Sarafina 2 (1996), 'a musical about the schoolgirl anti-apartheid activist of the first 1988 Sarafina production, now presented as an HIV social worker' (Squire, 2007: 33). The South African government spent R14 million on that production as part of its state funded HIV awareness campaign. However, the musical 'played in few places, sending out a partial message mainly about condoms, and [made] no reference to relationships, gender or even the main tenet of the then-dominant $\mathrm{ABC}$ [Abstinence; Be faithful; Use a condom] strategy, abstention' (Squire, 2007: 33). We must eat our suckers with the wrappers on was developed with young black South African dancers from the Market Theatre Laboratory. The Lab developed out of The Market Theatre (Johannesburg) as a 'place of learning' and 'with the goal of bringing diverse theatre skills to black youngsters' (Sassen, 2015: 89). 'I made this piece with the group', commented Orlin, 'when we needed to present an end of year piece as part of their course at the Market Theatre Lab. All of us felt that we needed to understand the loss and pain that was happening in our lives and around our lives' (quoted in Erasmus, 2009). The choreography explores the involvement of both the South African and international community in the discourse of the disease, from safer-sex information campaigns to the portrayal of South Africans affected by HIV and AIDS in the international press.

The second dance production studied in this essay is Nelisiwe Xaba's and Mocke J van Veuren's Uncles and Angels (2013), a piece created over a decade after Orlin's work. Xaba, a black South African, is from Soweto township in Gauteng and trained with the Johannesburg Dance Foundation and the Rambert Ballet in London. She has toured extensively either with her own dance works, such as Plasticization at the Barbican in London in 2007, has collaborated with artists such as fashion designer Gary Gibson of Strangelove in They Look at Me and That's All They Think (2009), and has worked with Orlin in Daddy, I've seen this piece six times before and I still don't know why they're hurting each other (1998). In Uncles and Angels, Xaba partners with white South African experimental filmmaker van Veuren. On the website for the Infecting the City festival held in Cape Town in 2014, it is noted that Van Veuren is known for 'experimenting with media technologies while engaging in critiques on issues of urban life, racial politics, gender and sexuality' and for his 'pedagogic approaches to dealing with HIV and AIDS-related issues in the learning environment' (Infecting the City, 2014). Xaba and van Veuren won the FNB Art Prize in 2013 (South Africa) for Uncles and 
Angels. In their 'interactive dance and video collaboration' (Infecting the City, 2014), Xaba and van Veuren examine how the discourse of HIV and AIDS has shaped the revival of uMkhosi Womhlanga (the Zulu Reed Dance) in South Africa, a traditional Zulu celebratory cultural event where young women present reeds to the King of the Zulu nation (currently King Goodwill Zwelithini). However, only those that pass a virginity test are allowed to do so. Xaba and van Veuren 'present a compelling examination of the manipulation of cultural heritage' (Infecting the City, 2014), as the ceremony was reintroduced in 1991 as a way of harnessing black female sexuality in reaction to the growing epidemic of HIV and AIDS in South Africa.

\section{Choreographing HIV and AIDS in Robyn Orlin's We must eat our suckers with the} wrappers on (2001)

In We must eat our suckers with the wrappers on, Orlin's choreography asserts that all South Africans are to be held accountable for the transmission and prevention of HIV. During the performance, the young black female and male dancers rhythmically beat red buckets, holding these close to their bodies as they move steadily around the stage. This rhythmic tempo creates connotations of the inexorable drive of the virus and how it has spread across South Africa, affecting the lives of all its inhabitants. Yet, at the same time, when the dancers move across the stage drumming their red plastic buckets they also represent how people have mobilised against HIV and AIDS and fought for access to antiretroviral treatments. The intense atmosphere is then broken when the dancers come together inserting their respective red buckets together, thereby parodying a sexual act and forming a chain.

At one point in We must eat our suckers with the wrappers on, a group of black dancers - men and women - remove the wrappers from red suckers (lollipops) and lick and stick the suckers onto a young female black dancer's face, closely circling around her illustrating how largely black South Africans are affected by HIV and AIDS and of this group, young black women make up the larger percentage due to a number of societal and physiological factors. This group of dancers shift into a tight arrangement, almost claustrophobic, then in an oppressive formation stand over the young female dancer. Overhead from a long wire connected to the lighting rig above the stage, a live feed camera hangs close to the young dancer's face. This live feed is projected onto the cyclorama at the back of the stage. The young female dancer moves to place herself to lie across a red bucket and begins to writhe. There is a strong suggestion here that for this young girl, her first sexual encounter has been distressing and possibly forced. Moreover, if considered as a 
choreographic representation of the young South Africa - only seven years since the first democratic national election - her onset of sexual maturity is occurring in a highly charged, at risk environment. Orlin points to the failure of the HIV-prevention campaigns in South Africa in the 1990s due to this naive response to the reality of gender disparities in many heterosexual relationships.

During this period of South African history, there were other immediate concerns that dominated the societal landscape such as the transition from the apartheid state to the first national democratically-elected government. According to political studies scholar Anthony Butler, the new government 'took office with a formidable strategy, on paper at least, for addressing HIV/AIDS' (2005: 593), but had to address gross inequalities in housing, education and basic access to utilities such as water and electricity that it had inherited from the previous racist regime. For a new government - and society - the capacity to limit the spread of HIV and AIDS was made more difficult because of these urgent concerns: 'The national AIDS plan [...] was insufficiently informed by the institutional and social realities of South Africa' and 'overestimated the economic, and especially human, resources at the disposal of the incoming government' (Butler, 2005: 593). In a way, the acceleration of HIV transmission was inexorable due to this perfect storm: this young state - represented here by the young black female dancer - faced the onslaught of the disease (the red suckers) whilst the rest of the world watched on via a live feed camera, and perhaps decided to look away.

Returning to Orlin's dance piece, it becomes extremely difficult to overlook a definitive moment in the choreography when the group of dancers in their circle loom directly over the young black female dancer. The immediacy of the circle around the young dancer blurs on the cyclorama and this image begins to resemble the schematic diagram of the HIV virus; surface proteins piercing out of a viral envelope that circles a capsid containing the genetic material of the HIV virus. The young dancer who has the suckers with their wrappers off - stuck on her face visually embodies the HIV virus and the mechanics of how the virus keys into our genetic material. Orlin's choreography emphasises to what extent it has become difficult to separate South Africa from the disease or the disease from South Africa, specifically black South Africans. South Africa has become synonymous with HIV and AIDS and black South Africans are seen as both 'victim's and 'agents' of the disease. The casting of a young black female as the central performer in this piece suggests how the global community infantilises and racialises South Africans and their local response to the epidemic in their own country. There is an international ignorance of the many local prevention and treatment campaigns as Squire highlights: 
In the developed world today, HIV often seems like an illness of other, poorer people. [...] Yet, as South Africa's example shows, developing-world countries also effectively plan and implement their own HIV policies and campaigns, work with regional and political allies in doing so, and produce powerful movements of HIVpositive and HIV-affected advocates and activists. In the developed world, the commitment and success of developing-world actions tends to be overlooked, the people behind them reduced to victims or recipients. (2007: 7)

We must eat our suckers with the wrappers on is an unsettling and at times anarchic performance for the non-South African viewer to watch as Orlin makes the spectator aware of their complicity in this prevailing attitude of reducing South Africans to "victims or recipients' of the disease. Orlin is a choreographer who agitates. She aims to raise her audience's hackles and force them to think about their actions and expose this neglect, thereby mirroring what sociologist Claire Laurier Decoteau refers to as an opportunity for 'us to avoid really thinking about our own complicity and complaisance' (2015: 237) in the stereotyping of South Africa and HIV and AIDS. At a later point in the choreography, the dancers pour red sand in a circle around the young dancer. This red sand signifies both the colour of the HIV and AIDS ribbon and the blood which transmits the virus. The dancers all go to stand on this sand and spread it around the stage thereby changing its shape and representing the spread of the disease. They soon come to the front of the stage, except the young dancer, and look directly at the audience, raising their fists in power salutes and singing protest songs against the disease. Again, Orlin's choreography shows the complex interweaving of the disease, how we can be accountable for its transmission and likewise activists in prevention and treatment campaigns. The dancers exit but soon return to the stage holding white handkerchiefs at various levels of height and ratios to their bodies. Onto these handkerchiefs are projected live feed images of the audience. This digital representation brings the audience onto the stage with the performers; they are no longer just observers but are involved in not only the performance's narrative but the discourse of HIV and AIDS in South Africa too; they cannot look away now. The dancers move to place the white handkerchiefs over the young black female dancer's face and quickly she is covered with these handkerchiefs still filled with the projected images. The young dancer later moves in an attempt to bring the live feed camera closer to her face as if she is trying to take control of the situation, perhaps take a hold of her own image, or directly address the audience. However, 
this is a struggle as a red spotlight engulfs her body reducing her representation to a simplistic stereotype of a South African living with HIV and AIDS, another statistic.

Orlin is a 'provocative choreographer' (Arts Admin, 2015), and is often criticised for her 'lack of subtlety' (Sulcas, 2011). In 2003, We must eat our suckers with the wrappers on was staged at The Barbican, London, and Zoe Anderson, in her review for The Independent (2003), writes that the piece is 'a 50-minute condom advert, in staging that veers from the naïve to the exploitative' and that it 'restate[s] the obvious'. Critical reception of Orlin's work has never been without controversy, and internationally and in South Africa '[s] he is both adored and reviled' (Friedman, 1995). Many critics fail to understand her use of parody and provocation in their reviews of her work, and instead see Orlin as possibly being exploitative of her dancers (Anderson, 2011). However, some critics recognise that Orlin's work is 'particularly adept at hitting her audience in the place where a laugh and a gasp are indistinguishable, where humour and horror merge in a disconcerting embrace' (Friedman, 1995). As a choreographer, she kinesthetically stages the gallows humour that South Africans exhibit as a type of coping mechanism in a society that is deeply affected by HIV and AIDS and other social problems due to the legacy of apartheid and colonialism. Orlin is acutely aware of this 'gallows humour', stating that 'the incredible thing about South Africa is that we really have a sense of humour about ourselves on both sides of the color bar [...] [w]e're not politically correct, and everything is in your face. A bit like my work' (quoted in Sulcas, 2011). It is through the irreverent, playful and uncomfortable moments in Orlin's work that sites of subversion are uncovered and points of resistance exercised.

In her book Ancestors and Antiretrovirals: The Biopolitics of HIV/AIDS in PostApartheid South Africa, Claire Laurier Decoteau argues that 'living with HIV/AIDS actually requires the mixture of biomedical and indigenous approaches to healing' (2015: 19, emphasis in original). In We must eat our suckers with the wrappers on, there is a section where the young female dancer is treated by another dancer who performs the part of an inyanga, a traditional/indigenous herbalist. In a rather tragicomedic parody, the healer/dancer treats the other dancer by giving her an enema. Karl Peltzer and Nolwandle Mngqundaniso in their research paper on 'Patients Consulting Traditional Health Practitioners in the Context of HIV/AIDS in Urban Areas in Kwazulu-Natal, South Africa' state that '[m]ost traditional health practitioners indicated that they had performed incisions or scarifications and half used an enema on their patients in the past three months' (2008: 374). Orlin's parody undermines the positive role that the indigenous healer might play in HIV prevention and AIDS treatment campaigns, but what must be understood here, is that at the time of the creation of this work 
(2001), there was no acknowledgement of how indigenous healers could support the medical and social campaigns to limit the transmission of the disease and aid treatment for people living with HIV and AIDS. Instead, the refusal by the medical profession to positively engage with the indigenous healing community meant that a number of myths and practices around HIV and AIDS and its treatment were circulated, such as the use of an enema to clean the body of the virus, and the limited practice of 'using new razor blades and sterilized enema equipment' (Peltzer and Nolwandle Mngqundaniso, 2008: 374). Decouteau refers to this as a "'myth of incommensurability" _ the ideology that indigenous (read "traditional") and biomedical (read “modern”) forms of healing are irreconcilably incompatible' (2015: 8). If there had been an alignment with indigenous healers and the medical community, there might have been far more effective HIV and AIDS prevention and treatment campaigns in operation, thereby reducing the spread of the disease; failure to do so has cost lives. We must eat our suckers with the wrappers on reminds the viewer that portrayal of HIV and AIDS must be multifarious as those that lives are shaped by it, are not homogenous; their experiences cannot be simply reduced to the colour red and condom use.

\section{Choreographing HIV and AIDS in Nelisiwe Xaba's and Mocke J van Veuren's Uncles and Angels (2013)}

At the opening of Uncles and Angels, the audience sees a silhouette of a pair of feet tottering on their toes behind a screen whilst music plays. The sounds of birds chirping and chickens clucking suggest an outside space. Xaba enters dressed in a small child's outfit, white with brightly coloured underpants sticking out. Her image is then digitally copied and manipulated multiple times onto the screen by way of van Veuren's use of a video projection software. Xaba kneels into a sitting position and checks if all the other young women - her duplicates have joined her to begin the procession in front of the current King of the Zulus, King Goodwill Zwelethini, as part of uMkhosi Womhlanga (the Zulu Reed Dance). This Zulu cultural event is held annually over two days in August/September in KwaZulu-Natal and during this young black women sing, dance, show off their beadmaking skills through their outfits, and are counselled on how to conduct themselves in the presence of men. Xaba then sits up and exits with her digital reproductions following her. We hear the sound of children playing, drawing attention to how young these women are who take part in the occasion. Xaba soon re-enters holding a stick referencing where the young black women hold reeds upright in front of their faces as they process in front of the king. The use of the software and its projected images of Xaba make reference to the processional nature of this dance as 
multiple replicas of Xaba follow her on the screen. In the programme notes for the Uncles and Angels production at the Theater der Welt festival held in Mannheim, Germany in 2014, the audience are informed of how around 30,000 young Zulu women in KwaZulu-Natal, South Africa, undergo virginity testing as part of uMkhosi Womhlanga and unfortunately a number of these young women 'rather commonly fall victim to male violence' (Theater der Welt, 2014: 58) surrounding the cultural event. Virginity testing entails older Zulu women checking the young black women if their hymens are still intact as proof that they have not engaged in sexual relations.

Xaba's choreography is minimal and almost sardonic in its execution. The movement is repetitive with Xaba entering and exiting and moving through a short sequence of choreography that contains a variation in costume or gestural movement whilst her form is simultaneously multiplied and projected on the screen by van Veuren. Theatre scholar Loren Kruger notes how 'Xaba's choreography for Uncles and Angels could be described as sampling' (2013: 98). Xaba reduces the structure of the choreographic movements to their fundamental structures and brings the processional nature of the choreography of the Reed Dance and the Domba (Snake) Dance down to its minimum, exposing its mechanics. The Domba Dance, known as the Snake Dance due to the python-like movements the dancers make, takes place approximately every three years in the Limpopo province of South Africa. It is performed by young Venda women as part of an initiation ceremony where they are taught about their roles and responsibilities as young black women in the Venda community. Later in Uncles and Angels, Xaba marches in with a stick, imitating drum majorettes, and thereby draws a parallel between the traditional practice of the Reed Dance and the modernity of the urban township experience, which also serves as a reminder that many of these black girls inhabit both worlds. The concepts of modernity and traditionalism are 'powerful ideological tools wielded in symbolic struggles for hegemony', but it must be noted that 'they are replete with contradictions and inconsistencies' (Decoteau, 2015: 173), such as the revival of the Reed Dance by the Zulu King in the 1990s. Decoteau's postcolonial perspective leads her to argue that:

South Africa's multiple, conjectural gender orders are riddled with contradictions and conflicts, but they are not the outcome of a simplistic colonial confrontation between 'traditional' and 'modern' gender orders. Such an approach not only ignores the processes of hybridisation that have occurred throughout the past four-hundred-plus 
years of South Africa's colonial history, but it also discounts the complex ways in which 'traditional' and 'modernity' are constantly being (re)invented. (2015:185)

This hybridity of traditionalism and modernity is what Xaba embodies in her performance by way of her choreographic interpretation of the Reed Dance, the Domba Dance and the drum majorettes. This is also explored in her choice of costume which visually shows the 'hybridisation' of concepts and ideologies of the traditional and modern throughout her piece. For instance, instead of wearing the traditional skirt that is made up of a variety of colourful beads as worn by the young Zulu girls in the Reed Dance, Xaba wears a white plastic skirt constructed out of contemporary materials. This criss-crossing of traditional and modern is apparent in the choreography when Xaba performs, with her live image digitally captured and copied onto the performance screen. This use of the live and digital emphasises how the Reed Dance and Domba Dance are hybrids of traditionalism and modernity.

Xaba, in an interview, comments that she and van Veuren never set out to make a piece about virginity testing but rather started out looking into the Domba Dance of the Venda people of South Africa. Originally Xaba wanted to explore the 'multiplication' of her body on screen, but soon she and van Veuren realised that Domba Dance was also about young girls and was 'similar to virginity testing and the Reed Dance' (Leiman, 2013). This then led them to consider how the popular practice of Drum Majoretting is likewise about putting the young female body on show. Uncles and Angels stresses the exhibitive qualities of these cultural practices and how the female form is primarily on display for the viewer who is often perceived to be male. In a review of the choreography at Dance Umbrella 2013 (South Africa), Loren Kruger writes that:

$[T]$ he title alludes to the exploitation of young girls by older men that is reinforced, in the view of Xaba and other black feminists, by the revival of the Reed Dance - the annual parade of young women before the Zulu king - and of virginity testing as a remedy for AIDS in a culture where the disease is spread overwhelmingly by promiscuous men who believe that sex with a virgin will protect or even cure them. (2013: 99)

The dancers are the Angels, the virgins, and they are paraded for the Uncles, the older men; Xaba 'brings the angelic women and the predatory uncles face to face' (Boisseau, 2013). Xaba and van Veuren discuss how there is an absence of the male physical presence in this 
work and that black female bodies on display are presented for the gaze of the male subject (Leiman, 2013). This is further reinforced in the performance's opening when Barry White's music begins to play. White's music suggests sex, however the track is then overlaid with the sound of children. This is uncomfortable to listen to, as there is a definite suggestion about the sexualisation of young girls by older men. Xaba notes:

I also question the way in which certain men use the confidence that the women and the children have in them to force them into activities aimed at satisfying their sexual pleasure. Moreover, it is often close relations, like the 'uncles', for example, who abuse the women. (cited in Boisseau, 2013)

The term Uncle also alludes to the court case in which the current President of South Africa Jacob Zuma, who, when serving as deputy president in 2005, went on trial for the rape of a close family female friend who was HIV-positive. During his testimony, he referred to himself as her uncle even though there were no family biological ties. Zuma was acquitted in 2006. However, his testimony on the stand 'that his reason for taking a shower after they had sex was to minimise his chances of contracting HIV' (Evans and Wolmarans, 2006) was ridiculed both locally and internationally. In their book Waiting to Happen: HIV/AIDS in South Africa, Liz Walker, Graeme Reid and Morna Cornell, stress that the South African constitution of 1996 'guarantees equality on the basis of sex, gender and sexual orientation; principles enshrined in the Bill of Rights and supported by several other clauses in the Constitution' (2004: 38). They point to the existence of moral taboos that are connected to sexual practice and sensitivity and how these are considered to be the woman's responsibility; women are viewed as the source of pollutants and are blamed for the transmission of HIV and AIDS (ibid.: 97). This is evident in the revival of the Reed Dance and its appropriation by politicians and cultural leaders in order to respond to the HIV and AIDS epidemic; it is the young black women who are checked and monitored for their sexuality, not the men. In an interview with Percy Zvomuya (2012), the Mail and Guardian's (South Africa) Arts and Features reporter, Xaba questioned the rationale that the Reed Dance limited the transmission of HIV and urged that there should be statistics provided to support this claim. This refusal to acknowledge how men are involved in the transmission of the HIV and AIDS is of great concern. By monitoring young black women and their sexuality in this invasive manner, the burden of responsibility for prevention of the virus's transmission is placed solely onto these young girls. 
Xaba does not negate the cultural practice of the Reed Dance in its totality. What she is doing is making the audience aware of how the Reed Dance is appropriated and utilised in order to put the responsibility of HIV and AIDS prevention wholly onto the shoulders of young black women and that it is their sexuality that is monitored and controlled. Xaba, through her use of the multiple digital projected images, indicates her connection to these young women, suggesting that she is part of the angels too. Like Orlin, Xaba is able to represent the complexities of the HIV and AIDS discourse in South Africa as she is not only an angel in the dance piece but also an auntie, when she enacts the checking of a young girl's hymen - dubbed the 'gold star' in Uncles and Angels. Xaba stages this with a comic turn and displays the use of 'gallows humour' similar to Orlin's in We must eat our suckers with the wrappers on. Xaba and van Veuren explain that ' $[\mathrm{t}]$ he production was meant to raise the issues involved and highlight the intrusion into a personal and sacred space by the "aunties" who checked whether the hymen was still intact' (Zvomuya, 2012). "“What happened to you? Only last year you were a virgin," says Xaba during the show, as if she is addressing a girl who is no longer a virgin' (Tsumele, 2012). Not only is the sexuality of young black women monitored, but it is older women who do so, and "most likely "victims" of the same process' ... 'participating in a patriarchal ritual' (Zvomuya, 2012). It is women - old and young who are made accountable for the monitoring of the transmission of HIV and AIDS and this reveals that women and men are both responsible for the prevention and treatment of HIV and AIDS.

\section{Closing}

Theatre scholar Ola Johansson asserts:

[I]n terms of a communicable disease ... HIV is a virus that always runs the risk of spreading if the right to one's own body and mind is violated. This applies not only to the current African state of affairs, but also to local governments, religious authorities, educational systems, non-governmental organizations, and (post)colonial ramifications of global trade policies. There is no way to get around this complex body of influences if one traces and pursues the cultural causes of the disease. (2007: 50)

Neither Orlin's We must eat our suckers with the wrappers on nor Xaba and van Veuren's Uncles and Angels are easy to watch, as both choreographers confront the viewer with 
provocative and sometimes unsettling scenes of a sexual nature. Both the choreographers and the filmmaker confront the gender and racial inequality at play in South African society.

Their use of parody reveals the contradictory and complex nature of HIV and AIDS discourse in South Africa and shows how these intricacies directly and indirectly shape the South African experience of the disease. The dance works explore how there is an appropriation of cultural practices in health campaigns as a response to HIV and AIDS. The choreographers invite the audience to consider their involvement in the transmission and treatment of HIV and AIDS. Drawing on South African contemporary dance's activist ethos, dancing bodies are mobilised through choreography to stress how the experience of the disease is distinctive and, in the context of South Africa, is very much gendered and racialised.

\section{Works cited}

Accone, D. (2001) 'Good Art Defies the Dance of Death' 6 March. www.artlink.co.za/news_article.htm?contentID=14400 (accessed 9 October 2015). Anderson, Z. (2013) 'We must Eat our Suckers with the Wrappers on, Barbican, London', The Independent 23 October 2013. www.independent.co.uk/arts-entertainment/theatredance/reviews/we-must-eat-our-suckers-with-the-wrappers-on-barbican-london93644.html (accessed 9 November 2015).

Arts Admin (no date) 'Artists We Work With/Robyn Orlin' www.artsadmin.co.uk/artists/robyn-orlin (accessed 9 October 2015).

Boisseau, R. (2013) 'La “nation arc-en-ciel”' se danse en Blancs et Noirs', Le Monde, 10 September (anon.transl.). www.numeridanse.tv/en/video/1810_uncles-and-angels (accessed 27 November 2015).

Butler, A. (2005) 'South Africa's HIV/AIDS Policy, 1994-2004: How Can It Be Explained?', African Affairs, Vol. 104, No. 417, pp. 591-614.

Campbell, C., Foulis, C. A., Malmane, S. and Sibya, Z. (2005) "'I Have an Evil Child at My House": Stigma and HIV/AIDS Management in a South African Community', American Journal of Public Health, Vol. 95, No. 5, May, pp. 808-815.

Decoteau, C. L. (2015) Ancestors and Antiretrovirals: The Biopolitics of HIV/AIDS in PostApartheid South Africa. Chicago: University of Chicago Press.

Erasmus, J. (2009) 'Robyn Orlin - Dancing Up a Storm', Brand South Africa, 4 March. www.brandsouthafrica.com/people-culture/arts-culture/robyn-orlin-4-3-9 (accessed 2 January 2017).

Evans, J. and Wolmarans, R. (2006) 'Timeline of the Jacob Zuma Trial', The Mail and 
Guardian, 21 March. http://mg.co.za/article/2006-03-21-timeline-of-the-jacob-zumarape-trial (accessed 1 September 2016).

Fassin, D. (2007) When Bodies Remember: Experience and Politics of AIDS in South Africa. Berkeley: University of California Press.

Friedman, H. (1995) 'Orlin Against the World', The Mail and Guardian, 22 September. http://mg.co.za/article/1995-09-22-orlin-against-the-world (accessed 9 November 2015).

Infecting the City (2014) 'Nelisiwe Xaba and Mocke J van Veuren'. http://www.infectingthecity.com/2014/cape-town/artists/nelisiwe-xaba-and-mocke-jvan-veuren (accessed 14 December 2015).

Johansson, O. (2007) 'Performative Interventions: African Community Theatre in the Age of AIDS', in Franko, M. (ed.) Ritual and Event: Interdisciplinary Perspectives. London and New York: Routledge.

Karim, S. S. A., G. Churchyard, Q. A. Karim, and S. D. Lawn (2009) 'HIV Infection and Tuberculosis in South Africa: An Urgent Need to Escalate the Public Health Response', The Lancet, Vol. 374, pp. 921-933.

Kruger, L. (2013) 'Dancing All Over Johannesburg, South Africa - Twenty-Fourth Annual Dance Umbrella', Theatre Journal, Vol. 65, No. 1, March, pp. 95-99.

Leiman, L. (2013) 'Uncles and Angels by Mocke J van Veuren and Nelisiwe Xaba.' http://10and5.com/2013/09/06/fnb-art-prize-winners-van-vueren-and-xaba-on-creatinguncles-angels (accessed 17 February 2016).

McNeill, F. G. (2011) AIDS, Politics, and Music in South Africa. New York: Cambridge University Press.

Peltzer, K. and N. Mngqundaniso (2008) 'Patients Consulting Traditional Health Practitioners in the Context of HIV/AIDS in Urban Areas in Kwazulu-Natal, South Africa', African Journal of Traditional, Complementary and Alternative Medicines, Vol. 5, No. 4, pp. 370-79.

Posel, D. (2011) “"Getting the Nation Talking About Sex": Reflections on the Politics of Sexuality and Nation-Building in Post-Apartheid South Africa', in Tamale, S. (ed.) African Sexualities: A Reader. Cape Town: Pambuzuka Press.

Sassen, R. (2015) 'Physical Theatre' in Middeke, M., Schneirer, P. P. and Homann, G. (eds.) The Methuen Drama Guide to Contemporary South African Theatre. London: Bloomsbury, pp. 77-92. 
Sichel, A. (2012) 'Gate-Crashing Prejudices and Perceptions: The Enduring Legacy of Artsand Dance Festivals in Post-Apartheid South Africa' in Friedman, S. (ed.) PostApartheid Dance: Many Bodies Many Voices Many Stories, edited by Sharon. Newcastle upon Tyne: Cambridge Scholars, pp. 107-25.

Squire, C. (2007) HIV in South Africa: Talking About the Big Thing. London and New York: Routledge.

Sulcas, R. (2011) 'Pointed Choreography, Rooted in South Africa', The New York Times, 10 February, http://www.nytimes.com/2011/02/11/arts/dance/11 orlin.html?_r=0 (accessed 9 November 2015).

Sutherland, A. (2013) 'Dramatic Spaces in Patriarchal Contexts: Constructions and Disruptions of Gender in Theatre Interventions About HIV', in Barnes, H. (ed.) Applied Drama and Theatre as an Interdisciplinary Field in the Context of HIVIAIDS in Africa. Amsterdam and New York: Rodopi, pp. 177-85.

The Human Sciences Research Council (2014) The South African National HIV Prevalence, Incidence and Behaviour Survey, 2012. Cape Town: HRSC.

Theater der Welt (2014), 'Programme Notes', http://itigermany.de/archiv.theaterderwelt/2014/de/index.html (accessed 30 December 2016).

Treichler, P. (1999) How to Have Theory in an Epidemic: Cultural Chronicles of AIDS. Durham: Duke University Press.

Tsumele, E. (2012) 'Taking a Critical Look at the Enforced Chastity of Girls', The Sowetan, 21 February. http://www.sowetanlive.co.za/entertainment/2012/02/21/taking-acritical-look-at-the-enforced-chastity-of-girls?PageSpeed=noscript (accessed 15 February 2016).

van Veuren, M. J. (2014) 'The Rhythms of Minutes and Uncles \& Angels - Two Projects', Research as Practice. Vol. 1, No. 1, pp. 34-9.

Walker, L., Reid, G. and Cornell, M. (eds) (2004) Waiting to Happen: HIV/AIDS in South Africa. Boulder and London: Lynne Reiner Publishers.

Zvomuya, P. (2012) 'Reed Dance Under Scrutiny', Mail and Guardian, 17 February, http://mg.co.za/article/2012-02-17-reed-dance-under-scrutiny (accessed 11 February 2016). 